\title{
Cyanide- and phenoxo-bridged heterobimetallic Fe(III)-Mn(III) complexes: Synthesis, crystal structures and magnetic properties
}

\author{
DAOPENG ZHANG*, PING WANG, KEXUN CHEN and XIA CHEN \\ College of Chemical Engineering, Shandong University of Technology, Zibo 255049, China \\ e-mail: dpzhang73@126.com
}

MS received 26 February 2014; revised 27 April 2014; accepted 28 April 2014

\begin{abstract}
By employing two mer-tricyanidoiron(III) precursors $\left[\mathrm{Ph}_{4} \mathrm{P}\right]\left[\mathrm{Fe}{ }^{\mathrm{III}}(\mathrm{pcq})(\mathrm{CN})_{3}\right]$ and $\left[\mathrm{Ph}_{4} \mathrm{P}\right]\left[\mathrm{Fe}^{\mathrm{III}}\right.$ $\left.(\mathrm{pzq})(\mathrm{CN})_{3}\right]$ as building blocks and a salen-tpye Schiff-base manganese (III) compound as assembling segment, two tetranuclear cyanide- and phenoxo- bridged heterobimetallic Fe(III)-Mn(III) complexes $\{[\mathrm{Mn}(\mathrm{saltmen})]$ $\left.\left[\mathrm{Fe}(\mathrm{pcq})(\mathrm{CN})_{3}\right]\right\}_{2} \cdot 2 \mathrm{CH}_{3} \mathrm{OH}(\mathbf{1})$ and $\left\{[\mathrm{Mn}(\text { saltmen })]\left[\mathrm{Fe}(\mathrm{pzq})(\mathrm{CN})_{3}\right]\right\}_{2} \cdot 2 \mathrm{CH}_{3} \mathrm{OH}(\mathbf{2})$ (pcq $=8$ - $($ pyridine-2carboxamido, $\mathrm{pzq}=8$-(pyrazine-2-carboxamido, saltmen ${ }^{2-}=N, N^{\prime}-(1,1,2,2$-tetramethylethylene)bis(salicylideneaminato)dianion) have been synthesized and characterized by elemental analysis, IR spectroscopy and $\mathrm{X}$-ray structure determination. Single X-ray analysis reveals their isostructural cyanide-bridged Fe(III)-Mn(III) binuclear structure. The binuclear entity is self-complementary through phenoxo oxygen from the neighbouring complex, giving cyanide- and phenoxo- bridged tetranuclear structure. Furthermore, under the help of the intermolecular $\pi-\pi$ interaction, these two complexes can be constructed into 1D infinite chain supramolecular structure. Investigation over magnetic susceptibilities reveals the overall ferromagnetic coupling between the adjacent $\mathrm{Fe}(\mathrm{III})$ and $\mathrm{Mn}$ (III) ions bridged by cyanide group with $J=5.34 \mathrm{~cm}^{-1}$ and $5.55 \mathrm{~cm}^{-1}$ for complexes $\mathbf{1}$ and $\mathbf{2}$, respectively.
\end{abstract}

Keywords. Cyanide-bridged; heterobimetallic; crystal structure; magnetic property.

\section{Introduction}

Over the past three decades, due to the well-known ability of the cyanide group to mediate exchange interactions between the paramagnetic centres, cyanidebridged complexes have been given continuous attention in molecule magnetism field. Till now, a large number of cyanide-bridged molecule-based magnetic materials with high- $T_{\mathrm{c}}$, single-molecule magnets (SMMs), single-chain magnets (SCMs), spin crossover (SCO) and photomagnetic materials with different types of structures ranging from discrete polynuclear compounds to one-dimensional chains and two- and threedimensional networks have been synthesized on the basis of rational selection of magnetic centres and cyanide-containing building blocks. ${ }^{1-15}$

Investigation results have revealed that the design and preparation of novel cyanide-containing building blocks of polycyanideiron(III) $\left[\mathrm{Fe}(\mathrm{L})(\mathrm{CN})_{m}\right]^{n-}$ (L represents blocking ligand) play an important role in the synthesis of cyanide-bridged molecular magnetic materials. So far a number of polycyanideiron(III) building

*For correspondence blocks including $\left[\mathrm{Fe}(\mathrm{L})(\mathrm{CN})_{5}\right]^{2-}(\mathrm{L}=1$-methylimidazole $),{ }^{16}\left[\mathrm{Fe}(\mathrm{L})(\mathrm{CN})_{4}\right]^{-}(\mathrm{L}=$ bipy, phen, bpym $),{ }^{17} \mathrm{fac}-$ $\left[\mathrm{Fe}(\mathrm{L})(\mathrm{CN})_{3}\right]^{-}\left(\mathrm{L}=\mathrm{Tp}, \mathrm{Tp}^{*}, \mathrm{pzTp}\right.$, tach $),{ }^{18-20}$ and mer $-\left[\mathrm{Fe}(\mathrm{L})(\mathrm{CN})_{3}\right]^{-}(\mathrm{L}=$ bpca, pzcq, mpzcq, qcq, pcq, icq $)^{21-23}$ and $\left[\mathrm{Fe}(\mathrm{L})(\mathrm{CN})_{2}\right]^{-}(\mathrm{L}=\mathrm{bpb}$ derivatives or salen $)^{24}$ have been designed, synthesized and employed in assembling into cyanide-bridged molecular magnetic materials. Among which, the tricyanoiron(III) precursor mer-[Fe $\left.\mathrm{FII}^{\mathrm{III}}(\mathrm{pcq})(\mathrm{CN})_{3}\right]^{-}$and its analogues have been proved to be suitable building blocks for the assembling of low-dimensional heterometallic cyanidebridged magnetic complexes. ${ }^{21-23}$ Being also interested in this type of cyanide-building blocks, we investigated the reactions of mer-tricyanoiron(III) building blocks $\left[\mathrm{Ph}_{4} \mathrm{P}\right]\left[\mathrm{Fe}^{\mathrm{III}}(\mathrm{pcq})(\mathrm{CN})_{3}\right]^{22 \mathrm{~d}, 23}$ (pcq = 8-(pyridine-2carboxamido) and $\left[\mathrm{Ph}_{4} \mathrm{P}\right]\left[\mathrm{Fe}^{\mathrm{III}}(\mathrm{pzq})(\mathrm{CN})_{3}\right]^{22 \mathrm{~b}, \mathrm{e}}(\mathrm{pzq}=$ 8-(pyrazine-2-carboxamido) with Schiff base manganese compound $\left[\mathrm{Mn}(\right.$ saltmen $\left.)\left(\mathrm{H}_{2} \mathrm{O}\right)_{2}\right] \mathrm{ClO}_{4} \quad\left(\right.$ saltmen $^{2-}=$ $\mathrm{N}, \mathrm{N}^{\prime}$-(1,1,2,2-tetramethylethylene)bis(salicylideneiminato)dianion) (scheme 1), resulting in two cyano and phenoxo oxygen atom mix-bridged tetranuclear heterobimetallic complexes. The synthesis, crystal structure and magnetic properties of $\{[\mathrm{Mn}(\mathrm{saltmen})][\mathrm{Fe}(\mathrm{pcq})$ $\left.\left.(\mathrm{CN})_{3}\right]\right\}_{2} \cdot 2 \mathrm{CH}_{3} \mathrm{OH} \quad(\mathbf{1})$ and $\{[\mathrm{Mn}$ (saltmen) $] \quad[\mathrm{Fe}$ (pzq) $\left.\left.(\mathrm{CN})_{3}\right]\right\}_{2} \cdot 2 \mathrm{CH}_{3} \mathrm{OH}$ will be described in this paper. 

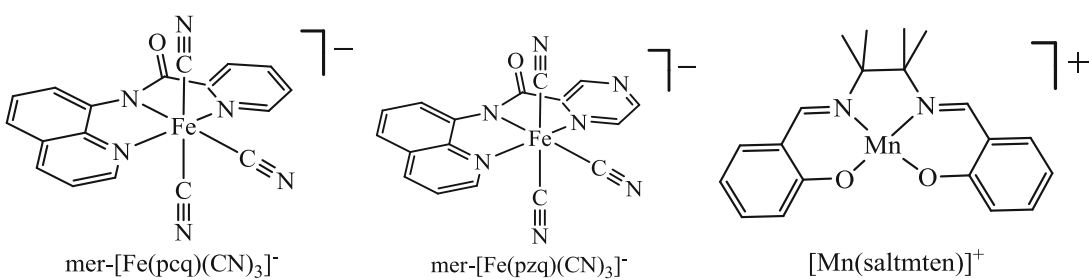

Scheme 1. The starting materials used to prepare complexes $\mathbf{1}$ and $\mathbf{2}$.

\section{Experimental}

\subsection{General procedures and materials}

All the reactions were carried out under an air atmosphere and all chemicals and solvents used in the synthesis were reagent grade without further purification. $\left[\mathrm{Ph}_{4} \mathrm{P}\right]\left[\mathrm{Fe}(\mathrm{pcq})(\mathrm{CN})_{3}\right],\left[\mathrm{Ph}_{4} \mathrm{P}\right]\left[\mathrm{Fe}(\mathrm{pzq})(\mathrm{CN})_{3}\right]$ and $[\mathrm{Mn}$ (saltmen $\left.)\left(\mathrm{H}_{2} \mathrm{O}\right)_{2}\right] \mathrm{ClO}_{4}$ were prepared according to the previous works. ${ }^{22 \mathrm{~b}, 23 \mathrm{a}, 25}$

Caution! Perchlorate salts of metal complexes with organic ligands are potentially explosive. They should be handled in small quantities with care.

\subsection{The preparation of complexes $\mathbf{1}$ and $\mathbf{2}$}

A solution containing $\mathrm{PPh}_{4}\left[\mathrm{Fe}(\mathrm{pcq})(\mathrm{CN})_{3}\right](0.1 \mathrm{mmol}$, $72.4 \mathrm{mg})$ or $\mathrm{PPh}_{4}\left[\mathrm{Fe}(\mathrm{pzq})(\mathrm{CN})_{3}\right](0.1 \mathrm{mmol}, 72.5 \mathrm{mg})$ in methanol $(10 \mathrm{~mL})$ was added to a stirred methanol and acetonitrile solution $(10 \mathrm{~mL}, 1: 1, \quad \mathrm{v}: \mathrm{v})$ of $\left[\mathrm{Mn}(\right.$ saltmen $\left.)\left(\mathrm{H}_{2} \mathrm{O}\right)_{2}\right] \mathrm{ClO}_{4}(0.1 \mathrm{mmol}, 51.3 \mathrm{mg})$. The mixture was stirred for a few minutes at room temperature and filtered. Then the filtrate was allowed to evaporate slowly without disturbance. The dark brown crystals so obtained several days later, which were suitable for X-ray diffraction, were collected by filtration, washed with cool methanol, and dried in air. Yield $51.1 \mathrm{mg}, 64.4 \%$. Anal. Calcd. For $\mathrm{C}_{78} \mathrm{H}_{72} \mathrm{Fe}_{2} \mathrm{Mn}_{2} \mathrm{~N}_{16} \mathrm{O}_{8}$ : C, 59.18; H, $4.58 \mathrm{~N}, 14.16$. Found: C, 59.36; H, 4.77; N, 13.95. Main IR bands $\left(\mathrm{cm}^{-1}\right): 2158,2120(\mathrm{~s}$, $\nu \mathrm{C} \equiv \mathrm{N}), 1616,1623(\mathrm{vs}, v \mathrm{C}=\mathrm{N})$.

Complex 2: $49.5 \mathrm{mg}, 62.5 \%$. Anal. Calcd. for $\mathrm{C}_{76} \mathrm{H}_{70} \mathrm{Fe}_{2} \mathrm{Mn}_{2} \mathrm{~N}_{18} \mathrm{O}_{8}$ : C, 57.59; H, 4.45; N, 15.91 . Found: C, 57.36; H, 4.27; N, 15.68. Main IR bands $\left(\mathrm{cm}^{-1}\right): 2160,2121 \quad(\mathrm{~s}, \nu \mathrm{C} \equiv \mathrm{N}), 1618,1625 \quad$ (vs, $v C=\mathrm{N})$.

\section{$2.3 X$-ray data collection and structure refinement}

Single crystals of all the complexes for X-ray diffraction analyses with suitable dimensions were mounted on the glass rod and the crystal data were collected on a Bruker SMART CCD diffractometer with a MoK $\alpha$ sealed tube ( $\lambda=0.71073 \AA$ ) at $293 \mathrm{~K}$, using a $\omega$ scan mode. The structures were solved by direct method and expanded using Fourier difference techniques

Table 1. Crystallographic data for complexes $\mathbf{1}$ and $\mathbf{2 .}$

\begin{tabular}{lcc}
\hline & $\mathbf{1}$ & $\mathbf{2}$ \\
\hline chemical formula & $\mathrm{C}_{78} \mathrm{H}_{72} \mathrm{Fe}_{2} \mathrm{Mn}_{2} \mathrm{~N}_{16} \mathrm{O}_{8}$ & $\mathrm{C}_{76} \mathrm{H}_{70} \mathrm{Fe}_{2} \mathrm{Mn}_{2} \mathrm{~N}_{18} \mathrm{O}_{8}$ \\
$\mathrm{FW}$ & 1583.10 & 1585.08 \\
crystal system & monoclinic & monoclinic \\
Space group & $\mathrm{C} 2 / \mathrm{c}$ & $\mathrm{C} 2 / \mathrm{c}$ \\
$a / \AA$ & $24.925(6)$ & $24.939(8)$ \\
$b / \AA$ & $12.898(3)$ & $12.805(3)$ \\
$c / \AA$ & $22.151(5)$ & $22.346(6)$ \\
$\alpha /$ deg & 90 & 90 \\
$\beta /$ deg & $92.724(4)$ & $92.615(8)$ \\
$\gamma /$ deg & 90 & 90 \\
$V / \AA^{3}$ & $7113(3)$ & $7129(3)$ \\
$Z$ & 4 & 4 \\
completeness & $97.6 \%$ & $99.7 \%$ \\
$F(000)$ & 3272 & 3272 \\
$\theta /$ deg & 1.78 to 24.83 & 1.79 to 25.01 \\
$G O F$ & 1.023 & 1.021 \\
$R_{1}[I>2 \sigma(I)]$ & 0.0522 & 0.0532 \\
$w R_{2}($ all data $)$ & 0.1564 & 0.1604 \\
\hline
\end{tabular}


with the SHELXTL-97 program package. The nonhydrogen atoms were refined anisotropically, and the hydrogen atoms were introduced as fixed contributors and assigned isotropic displacement coefficients $\mathrm{U}(\mathrm{H})=1.2 \mathrm{U}(\mathrm{C})$ or $1.5 \mathrm{U}(\mathrm{C})$, and their coordinates were allowed to ride on their respective carbons using SHELXL97. For the disordered contents, the partially occupied atoms were refined isotropically. Details of the crystal parameters, data collection and refinement are summarized in table 1.

\section{Results and Discussion}

\subsection{Synthesis and general characterization}

Due to the facile preparation and the large spin state $(\mathrm{S}=2)$ as well as the usually negative magnetic anisotropy of the central $\mathrm{Mn}$ (III) ions, manganese(III)salen types of compounds with $\mathrm{N}_{2} \mathrm{O}_{2}$ equatorial salentype ligands ( salen $=\mathrm{N}$, N-ethylene-bissal icylideneiminate) have been widely used to prepare cyanide-bridged magnetic complexes by assembling with many cyanidecontaining building blocks. ${ }^{26}$ In this paper, we investigated the reactions of $\left[\mathrm{Mn}(\right.$ salmten $\left.)\left(\mathrm{H}_{2} \mathrm{O}\right)_{2}\right] \mathrm{ClO}_{4}$ with $\left[\mathrm{Ph}_{4} \mathrm{P}\right]\left[\mathrm{Fe}(\mathrm{pcq})(\mathrm{CN})_{3}\right]$ or $\left[\mathrm{Ph}_{4} \mathrm{P}\right]\left[\mathrm{Fe}(\mathrm{pzq})(\mathrm{CN})_{3}\right]$, and obtained two binuclear cyanide-bridged Fe(III)-Mn(III) complexes. Furthermore, due to the coordination of the phenoxo oxygen atoms from the neighbouring complex to the $\mathrm{Mn}$ (III) atom, the neutral binuclear unit can be self-assembled into cyano and phenoxo oxygen mix-bridged tetranuclear entity. The crystal structure of these two complexes is different from the reported compound $\left[\mathrm{Fe}(\mathrm{pcq})(\mathrm{CN})_{3} \mathrm{Mn}\right.$ (saltmen $\left.)\left(\mathrm{CH}_{3} \mathrm{OH}\right)\right] \cdot \mathrm{CH}_{3}$ $\mathrm{OH}^{22 \mathrm{~d}}$ which belongs to cyanide-bridged binuclear type with the two axial positions of the $\mathrm{Mn}$ (III) ion occupied by the $\mathrm{N}$ atom of the bridging cyanide group and the $\mathrm{O}$ atom of the coordinated solvent methanol molecule. The two cyanide-bridged heterometallic complexes have been characterized by IR spectroscopy. In the IR spectra of complexes $\mathbf{1}$ and $\mathbf{2}$, two sharp peaks due to the cyanide-stretching vibration were observed at about 2125 and $2155 \mathrm{~cm}^{-1}$ respectively, indicating the presence of bridging and nonbridging cyanide ligands in these complexes.

\subsection{Crystal structures of complexes $\mathbf{1}$ and $\mathbf{2}$}

Some important structural parameters for complexes $\mathbf{1}$ and $\mathbf{2}$ are collected in table 2. The neutral tetranuclear structure for these two complexes, their representative 1D supramolecular structure formed by the intermolecular $\pi-\pi$ interactions and cell packing
Table 2. Selected bond lengths $(\AA)$ and angles $\left(^{\circ}\right)$ for complexes $\mathbf{1}$ and $\mathbf{2}$.

\begin{tabular}{lcc}
\hline & $\mathbf{1}$ & $\mathbf{2}$ \\
\hline $\mathrm{Fe}(1)-\mathrm{C}(1)$ & $1.952(6)$ & $1.962(6)$ \\
$\mathrm{Fe}(1)-\mathrm{C}(2)$ & $1.945(6)$ & $1.958(6)$ \\
$\mathrm{Fe}(1)-\mathrm{C}(3)$ & $1.958(7)$ & $1.968(7)$ \\
$\mathrm{Fe}(1)-\mathrm{N}(4)$ & $1.984(4)$ & $1.970(4)$ \\
$\mathrm{Fe}(1)-\mathrm{N}(5)$ & $1.872(4)$ & $1.881(4)$ \\
$\mathrm{Fe}(1)-\mathrm{N}(6)$ & $1.968(4)$ & $1.956(4)$ \\
$\mathrm{Mn} 1-\mathrm{N} 1$ & $2.211(5)$ & $2.229(5)$ \\
$\mathrm{Mn}(1)-\mathrm{N}(8)$ & $1.971(4)$ & $1.981(4)$ \\
$\mathrm{Mn}(1)-\mathrm{N}(9)$ & $1.995(4)$ & $1.974(4)$ \\
$\mathrm{Mn} 1-\mathrm{O} 1$ & $1.895(3)$ & $1.863(4)$ \\
$\mathrm{Mn} 1-\mathrm{O} 2$ & $1.861(4)$ & $1.881(3)$ \\
$\mathrm{Mn} 1-\mathrm{O} 2 \# 1$ & $2.620(3)$ & $2.638(1)$ \\
& & \\
$\mathrm{C}(1)-\mathrm{N}(1)-\mathrm{Mn}(1)$ & $163.3(5)$ & $163.5(5)$ \\
$\mathrm{N}(1)-\mathrm{C}(1)-\mathrm{Fe}(1)$ & $174.6(5)$ & $174.5(5)$ \\
$\mathrm{N}(2)-\mathrm{C}(2)-\mathrm{Fe}(1)$ & $177.3(5)$ & $177.4(5)$ \\
$\mathrm{N}(3)-\mathrm{C}(3)-\mathrm{Fe}(1)$ & $177.7(6)$ & $177.6(6)$ \\
\hline
\end{tabular}

Symmetry transformations used to generate equivalent atoms: \#1: $-\mathrm{x}+1 / 2, \mathrm{y}+3 / 2,-\mathrm{z}+3 / 2$.

diagram along $a$ axis are shown in figures 1-3, respectively.

As can be found in table 2, complexes $\mathbf{1}$ and $\mathbf{2}$ are isostructural and crystallize in monoclinic space group $\mathrm{C} 2 / \mathrm{c}$. In these two complexes, the tricyanidecontaining building block acts as a monodentate ligand through one of its two axial cyanide groups towards the $\mathrm{Mn}$ (III) ion, affording a cyanide-bridged binuclear $\mathrm{Fe}-\mathrm{Mn}$ structure. The $\mathrm{Fe}$ (III) ion is coordinated by three $\mathrm{N}$ atoms of tridentate organic ligand and three $\mathrm{C}$ atoms of cyanide groups in mer-position, so that involved in a distorted octahedral geometry, which can be proved by the bond parameters around for the $\mathrm{Fe}(\mathrm{III})$ ion (table 2). The parameters around the $\mathrm{Fe}$ (III) ion is almost same to those found in the free $\left[\mathrm{Fe}(\mathrm{pcq})(\mathrm{CN})_{3}\right]^{-}$ or $\left[\mathrm{Fe}(\mathrm{pzq})(\mathrm{CN})_{3}\right]^{-}, 22 \mathrm{~b}, \mathrm{e}, 23 \mathrm{a}$ indicating that the coordination of the cyanide group to the $\mathrm{Mn}$ (III) ion has no obvious influence on the geometry of the Fe(III) ion. The bond angles of $\mathrm{Fe}-\mathrm{C} \equiv \mathrm{N}$ in a very narrow range of $174.5(5)-177.7(6)^{\circ}$ clearly indicate that the three atoms are in a good linear configuration.

The coordination sphere for the Mn atom in these two complexes is also described as a distorted octahedral, in which four equatorial positions are occupied by two $\mathrm{N}$ atoms and two $\mathrm{O}$ atoms from the Schiff base ligand, and the other two axial ones come from the $\mathrm{N}$ atoms of the bridging cyanide group and the phenoxo oxygen atom of the neighbouring binuclear molecule. As shown in table 2, the average distances between the Mn atom and the $\mathrm{N}, \mathrm{O}$ atoms of the Schiff-base ligand in complexes $\mathbf{1}$ and $\mathbf{2}$ are 1.983 and $1.978 \AA$ respectively, 


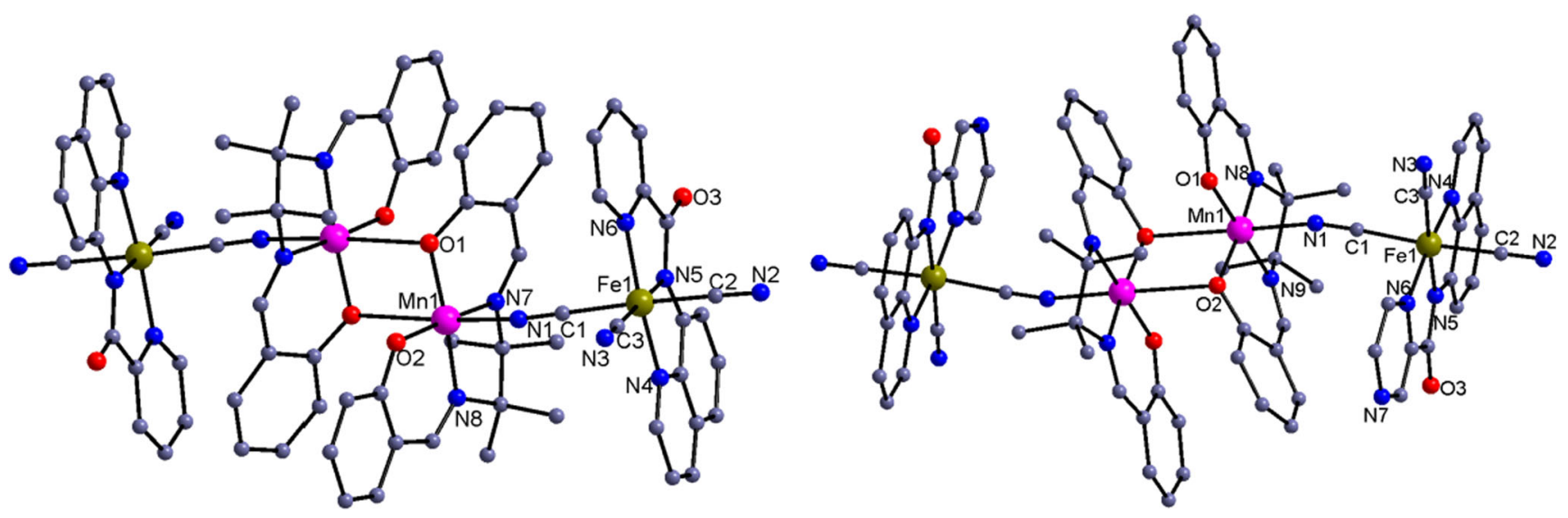

Figure 1. The tetranuclear structure of complexes 1(left) and 2(right). The solvent molecules and all the $\mathrm{H}$ atoms are omitted for clarity.

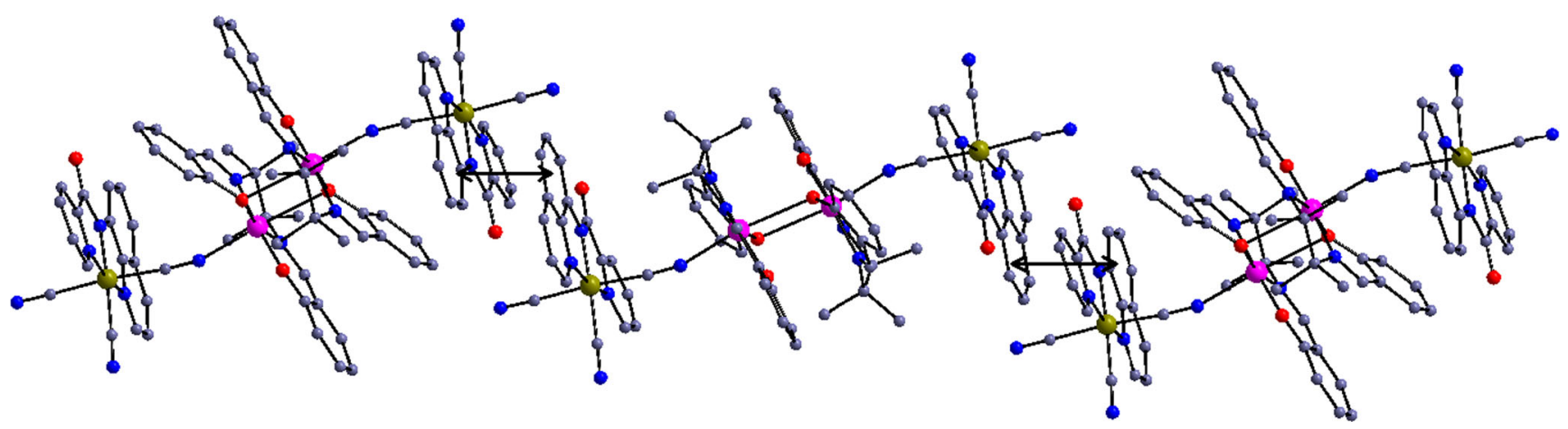

Figure 2. The 1D single chain structure constructed by intermolecular $\pi-\pi$ interaction for complexes $\mathbf{1}$ and $\mathbf{2}$. The solvent molecules and all the $\mathrm{H}$ atoms are omitted for clarity.

while the $\mathrm{Mn}-\mathrm{N}_{\text {cyanide }}$ and $\mathrm{Mn}-\mathrm{O}_{\text {phenoxo }}$ bond lengths are 2.211(5), 2.620(3) $\AA$ and 2.229(5), 2.638(1) $\AA$, which gives further information about the elongation octahedron surrounding the $\mathrm{Mn}(\mathrm{III})$ ion, typically accounting for the well-known JahnTeller effect. The angles of $\mathrm{C}(1) \equiv \mathrm{N}(1)-\mathrm{Mn}(1)$ in these two complexes are with the values to about $163^{\circ}$, indicative of the fact that these three atoms deviate slightly from a linear configuration. The bond parameters around the $\mathrm{Mn}$ (III) ion in complexes $\mathbf{1}$ and $\mathbf{2}$ are basically comparable to those found in $\left[\mathrm{Fe}(\right.$ pcq $)(\mathrm{CN})_{3} \mathrm{Mn}$ (saltmen $\left.)\left(\mathrm{CH}_{3} \mathrm{OH}\right)\right]$. $\mathrm{CH}_{3} \mathrm{OH},{ }^{22 \mathrm{~d}}$ while the $\mathrm{C} \equiv \mathrm{N}-\mathrm{Mn}$ bond angle here is obviously larger than that in the above complex $\left(163^{\circ}\right.$ vs. $\left.153.2(2)^{\circ}\right)$. The intramolecular $\mathrm{Fe}^{\mathrm{III}}-\mathrm{Mn}^{\mathrm{III}}$ separation through bridging cyanide(s) in complexes $\mathbf{1}$ and 2 are 5.221 and $5.255 \AA$, respectively, which are obviously shorter than the shortest intermolecular metalmetal distance with the value of about $7.61 \AA$. It is worth noting that, with the help of the intermolecular $\pi-\pi$ interaction, these two complexes can be linked into one-dimensional supramolecular chain structure (figure 2).

\subsection{Magnetic properties of complexes 1 and $\mathbf{2}$}

The temperature dependence of $\chi_{\mathrm{m}} T$ for complexes 1 and 2 measured in the range of $2-300 \mathrm{~K}$ is shown in figure 4. The $\chi_{\mathrm{m}} T$ value at $300 \mathrm{~K}$ is $3.59 \mathrm{emu} \mathrm{K} \mathrm{mol}^{-1}$ for $\mathbf{1}$ and $3.58 \mathrm{emu} \mathrm{K} \mathrm{mol}^{-1}$ for $\mathbf{2}$, respectively, which are slightly higher than the spin only value $3.38 \mathrm{emu} \mathrm{K} \mathrm{mol}^{-1}$ for one high spin $\mathrm{Mn}$ (III) $(S=2)$ and one low spin $\mathrm{Fe}(\mathrm{III})(\mathrm{S}=1 / 2)$. The $\chi_{\mathrm{m}} T$ value increases slowly to about $4.00 \mathrm{emu} \mathrm{K} \mathrm{mol}^{-1}$ with the temperature decreasing about $50 \mathrm{~K}$. After that, the $\chi_{\mathrm{m}} T$ value starts to increase rapidly to the maximum of 4.87 and $4.97 \mathrm{emu} \mathrm{K} \mathrm{mol}^{-1}$ at about $6 \mathrm{~K}$ for complexes 1 and 2, respectively, and then the $\chi_{\mathrm{m}} T$ value decreases sharply to $4.24 \mathrm{emu} \mathrm{K} \mathrm{mol}^{-1}$ for $\mathbf{1}$ and $3.90 \mathrm{emu} \mathrm{K} \mathrm{mol}^{-1}$ for $\mathbf{2}$ with the temperature down to $2 \mathrm{~K}$. The changing tendency of the $\chi_{\mathrm{m}} T$ curve gives primary information that there exists overall ferromagnetic coupling between the cyanide-bridged $\mathrm{Mn}$ (III) and $\mathrm{Fe}$ (III) ions in the above two complexes.

The inset of figure 4 shows the field-dependent magnetization measured up to $50 \mathrm{kOe}$ at $2 \mathrm{~K}$ for these two 


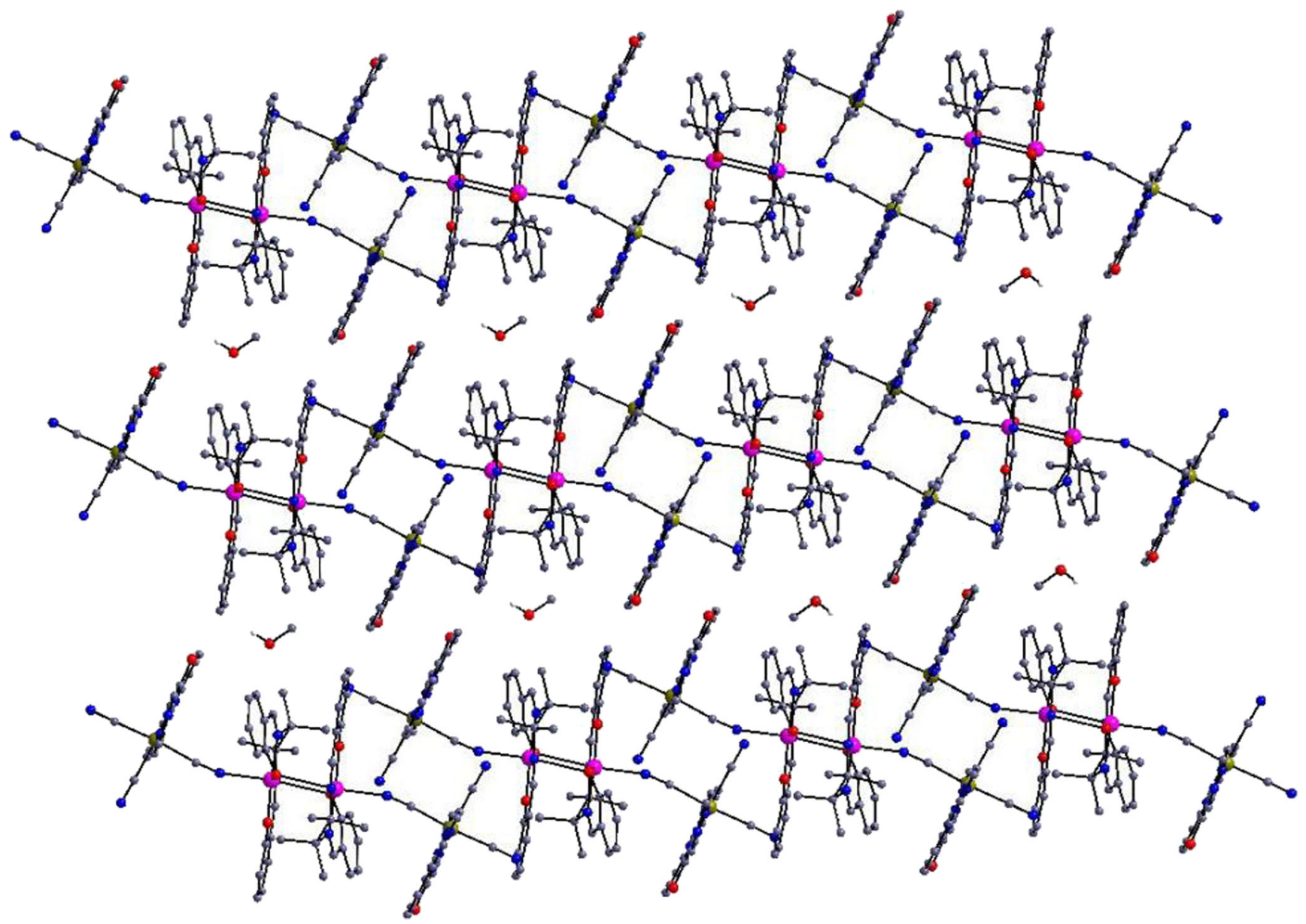

Figure 3. The representative cell packing diagram for complexes $\mathbf{1}$ and $\mathbf{2}$ along $b$ axis. All the non-solvent hydrogen atoms are omitted for clarity.
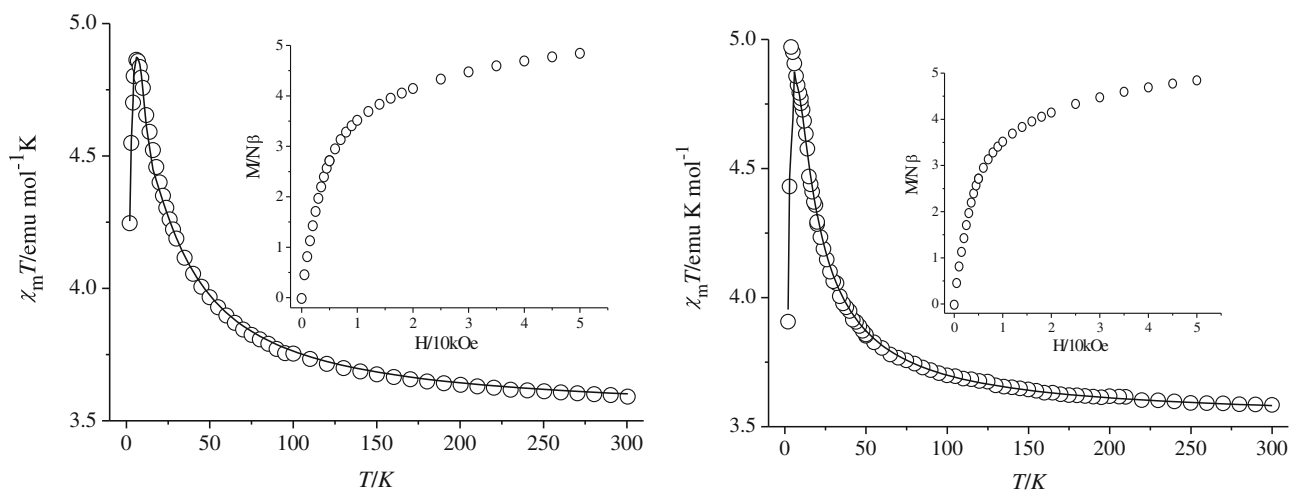

Figure 4. Temperature dependence of $\chi_{m} T$ of complexes 1 (left) and 2 (right). Inset: Field dependence of magnetization of 2 at $2 \mathrm{~K}$.

complexes. The magnetization increases rapidly up to $10 \mathrm{kOe}$, and then the curve becomes relatively even and attains the maximum value at about $4.90 \mathrm{~N} \beta$. These data can also confirm that there exist ferromagnetic coupling interactions between the $\mathrm{Fe}(\mathrm{III})$ and $\mathrm{Mn}(\mathrm{III})$ ions in the three complexes.
As can be found from the structural data of complexes $\mathbf{1}$ and $\mathbf{2}$, there are two different magnetic coupling pathways, cyano bridges $(J)$ and phenoxo bridges $\left(J^{\prime}\right)$. It has been reported by Miyasaka et al. that $|J| \gg\left|J^{\prime}\right|,{ }^{25,27,28}$ therefore the magnetic coupling through phenoxo bridges can be safely neglected during 
the fitting process. On the basis of the binuclear $\mathrm{Fe}^{\mathrm{III}}$ $\mathrm{Mn}^{\mathrm{III}}$ ( $S=1 / 2$ and 2 ) model, the magnetic susceptibilities for these two complexes can be fitted by the expression below derived from the isotropic exchange spin Hamiltonian $\hat{H}=-2 J \hat{\mathrm{S}}_{\mathrm{Fe}} \hat{\mathrm{S}}_{\mathrm{Mn}}$ :

$$
\begin{aligned}
\chi_{d} & =\frac{N g^{2} \beta^{2}}{2 k T} \frac{35 \exp (2 J / k T)+10 \exp (-3 J / k T)}{6 \exp (2 J / k T)+4 \exp (-3 J / k T)} \\
\chi_{m} & =\frac{\chi_{d}}{1-\chi_{d}\left(2 z J^{\prime} / N g^{2} \beta^{2}\right)}
\end{aligned}
$$

The best-fit parameters obtained are $J=5.34(3) \mathrm{cm}^{-1}$, $\mathrm{g}=2.01(2), z J^{\prime}=-0.11(5) \mathrm{cm}^{-1}, R=2.91 \times 10^{-5}$ for complex 1 and $J=5.55(3) \mathrm{cm}^{-1}, \mathrm{~g}=2.01(4)$, $z J^{\prime}=-0.13(6) \mathrm{cm}^{-1}, R=3.14 \times 10^{-5}$ for complex 2 , respectively. These results further testified the ferromagnetic coupling between the neighbouring Fe-Mn ion pair bridged by cyanide group, which is also consistent with the fact that almost all the cyanide-bridged $\mathrm{Fe}(\mathrm{III})-\mathrm{Mn}$ (III) complexes show the ferromagnetic coupling nature.

\section{Conclusion}

We obtained two heterobimetallic cyanide- and phenoxo- co-bridged tetranuclear clusters with two mer-tricyanidoiron(III) precursors as cyanide building blocks and schiff-base manganese(III) compound as assembling segment, which can be linked into a one-dimensional infinite chain supramolecular structure depending on the intermolecular $\pi-\pi$ interaction. Investigation over the magnetic properties of these two complexes reveals ferromagnetic coupling between the adjacent $\mathrm{Mn}$ (III) and $\mathrm{Fe}(\mathrm{III})$ ions through the linear cyanide bridge.

\section{Supplementary Information}

The CIF tables of $\mathbf{1}$ and $\mathbf{2}$ have been deposited at the Cambridge Crystallographic Data Centre with the deposition numbers CCDC 985441 and 985442, respectively.

\section{Acknowledgement}

The authors acknowledge the support of the Natural Science Foundation of China (21171107), the Natural Science Foundation of Shandong Province (ZR201 1BM008) and the Science and Technology Project of High Education, Shandong Province (No. J11LB09).

\section{References}

1. Verdaguer M, Bleuzen A, Marvaud V, Vaissermann J, Seuleiman M, Desplanches C, Scuiller A, Train C, Garde R, Gelly G, Lomenech C, Rosenman I, Veillet P, Cartier dit Moulin C and Villain F 1999 Coord. Chem. Rev. 1921023 and references within

2. (a) Visinescu D, Fabelo, O, Ruiz-Peìrez Lloret $F$ and Julve M 2010 CrystEngComm. 12 2454; (b) Nastase S, Maxim C, Andruh M, Cano J, Ruiz-Peìrez C, Faus J, Lloret F and Julve M 2011 Dalton Trans. 404898

3. (a) Entley W R and Girolami G S 1995 Science $\mathbf{2 6 8}$ 397; (b) Ferlay S, Mallah T, Ouahès R, Veillet $\mathrm{P}$ and Verdaguer M 1995 Nature 378 701; (c) Sato O, Iyoda T, Fujishima A and Hashimoto K 1996 Science 27149

4. (a) Long J, Chamoreau L M, Mathonière $C$ and Marvaud V 2008 Inorg. Chem. 47 22; (b) Bleuzen A, Marvaud V, Mathonière C, Sieklucka B and Verdaguer M 2009 Inorg. Chem. 483453

5. Rodríguez-Velamazán J A, González M A, Real J A, Castro M, Muñoz M C, Gaspar A B, Ohtani R, Ohba M, Yoneda K, Hijikata Y, Yanai N, Mizuno M, Ando H and Kitagawa S 2012 J. Am. Chem. Soc. 1345083

6. Jeon I R, Calancea S, Panja A, Piñero Cruz D M, Koumousi E S, Dechambenoit P, Coulon C, Wattiaux A, Rosa P, Mathonière C and Clérac R 2013 Chem. Sci. 4 2463.

7. (a) Liu C M, Xiong R G, Zhang D Q and Zhu D B 2010J. Am. Chem. Soc. 132 4044; (b) Zhang Y Z and Sato O 2010 Inorg. Chem. 491271

8. (a) Wen H R, Wang C F, Li Y Z, Zuo J L, Song Y and You X Z 2006 Inorg. Chem. 45 7032; (b) Yao M X, Zheng Q, Cai X M, Li Y Z, Song Y and Zuo J L 2012 Inorg. Chem. $\mathbf{5 1} 2140$

9. Freedman D E, Jenkins D M, Iavarone A T and Long J R 2008 J. Am. Chem. Soc. 1302884

10. (a) Sutter J P, Dhers S, Rajamani R, Ramasesha S, Costes J P, Duhayon C and Vendier L 2009 Inorg. Chem. 48 5820; (b) Goodwin A L, Kennedy B J and Kepert C 2009 J. Am. Chem. Soc. 1316334

11. (a) Zhang D P, Zhang L F, Wang H L, Chen Y T, Ni Z $\mathrm{H}$, Wernsdorfer W and Jiang J Z 2010 Chem. Commun. 46 3550; (b) Zhang D P, Wang H L, Chen Y T, Ni Z H, Tian L J and Jiang J Z 2009 Inorg. Chem. 4811215

12. Wang S, Ding X H, Zuo J L, You X Z and Huang W 2011 Coord. Chem. Rev. 2551713

13. Sieklucka B, Podgajny R, Korzeniak T, Nowicka B, Pinkowicz D and Koziel M 2011 Eur. J. Inorg. Chem. 305

14. Atanasov M, Comba P and Daul C A 2008 Inorg. Chem. 472449

15. Bleuzen A, Marvaud V, Mathoniere C, Sieklucka B and Verdaguer M 2009 Inorg. Chem. 483453

16. Ni W W, Ni Z H, Cui A L, Liang X and Kou H Z 2007 Inorg. Chem. $\mathbf{4 6} 22$

17. Toma L M, Lescouëzec R, Pasán J, Ruiz-Pérez C, Vaissermann J, Cano J, Carrasco R, Wernsdorfer W, Lloret F and Julve M $2006 \mathrm{~J}$. Am. Chem. Soc. 1284842

18. (a) Liu, W, Wang C F, Li Y Z, Zuo J L and You X Z 2006 Inorg. Chem. 45 10058; (b) Wang S, Zuo J L, Zhou H C, Choi H J, Ke Y, Long J R and You X Z 2004 Angew. Chem. Int. Ed. $\mathbf{4 3} 5940$ 
19. Li D, Parkin S, Wang G, Yee G T, Clérac R, Wernsdorfer W and Holmes S M $2006 \mathrm{~J}$. Am. Chem. Soc. 128 4214

20. Yang J Y, Shores M P, Sokol J J and Long J R 2003 Inorg. Chem. 421403

21. Lescouëzec R, Vaissermann J, Toma L M, Carrasco R, Lloret F and Julve M 2004 Inorg. Chem. 432234

22. (a) Kim Jae II, Kwak H Y, Yoon J H, Ryu D W, Yoo I Y, Yang N, Cho B K, Park J G, Lee H and Hong C S 2009 Inorg. Chem. 48 2956; (b) Kim Jae II, Yoo H S, Koh E K, Kim H C and Hong C S 2007 Inorg. Chem. 46 8481; (c) Yoo I Y Ryu D W, Yoon J H, Sohn A R, Lim K S, Cho B K, Koh E K and Hong C S 2012 Dalton Trans. 41 1776; (d) Senapati T, Pichon, C Ababei R Mathonière C and Clérac R 2012 Inorg. Chem. 51 3796; (e) Kim Jae II, Yoon J H, Kwak H Y, Koh E K and and Hong C S 2008 Eur. J. Inorg. Chem. 2756

23. (a) Ni Z H, Kou H Z, Zhang L F, Ni W W, Jiang Y B, Cui A L, Ribas J and Sato O 2005 Inorg. Chem. 44 9631; (b) Zhang D P, Bian Y Z, Qin J, Wang P and Chen X 2014 Dalton Trans. 43945

24. (a) Ni Z H, Zhang L F, Tangoulis V, Wernsdorfer W, Cui A L, Sato O and Kou H Z 2007 Inorg. Chem. 46 6029; (b) Zhang D P, Wang H L, Chen Y T, Ni Z H, Tian L J and Jiang J Z 2009 Inorg. Chem. 48 5488; (c) Zhang D P, Zhao Z D, Wang P and Chen X 2012 Bull. Korean Chem. Soc. 33 1581; (d) Zhang D P, Wang H L, Chen Y T, Zhang L F, Tian L J, Ni Z H and Jiang J Z 2009 Dalton Trans. 9418

25. Miyasaka H, Matsumoto N, Okawa H, Re N, Gallo E and Floriani C 1996 J. Am. Chem. Soc. 118981

26. Miyasaka H, Saitoh A and Abe S 2007 Coord. Chem. Rev. 251 2622. and references therein

27. Ferbinteanu M, Miyasaka H, Wernsdorfer W, Nakata K, Sugiura K, Yamashita M, Coulon C and Clérac R 2005 J. Am. Chem. Soc. 1273090

28. Miyasaka, Okawa H, Miyazaki A and Enoki T 1998 Inorg. Chem. 374878 